\title{
The Morphology of the 'Flowers' of Cephalotaxus ${ }^{1}$.
}

\author{
BY \\ W. C. WORSDELL, F.L.S. \\ With Plate XXXV.
}

T HAVE lately, through the kindness of Miss M. Benson,

1 Lecturer in Botany at the Royal Holloway College, Egham, had placed at my disposal for investigation some abnormal female flowers of Cephalotaxus Fortunei, to the study of which a large part of the present memoir will be devoted.

I desire, however, to take the present favourable opportunity to enter into a general consideration of the morphology of the 'flowers' of both sexes in this important genus, for it appears to me that some uncertainty prevails with regard to the real morphological nature and relationships of the flowers. This is due in part to the fact that Cephalotaxus is much less frequent in gardens and parks than its ally Taxus, and in part to the minuteness and obscure position of the flowers.

\section{The Structure of the Male Flower.}

In the axils of the foliage-leaves of the previous year are borne small stalked, somewhat globose cones or capitula, the bracts of which are arranged spirally $(\mathrm{Pl} \text {. XXXV, Fig. I })^{2}$. In the axil of each bract of the cone is placed a short axis bearing

1 From the Jodrell Laboratory, Royal Botanic Gardens, Kew.

2 This figure is taken from a photograph, for which I am indebted to Mr. L. A. Boodle, F.L.S.

[Annals of Botany, Vo1. XV. No. LX. December, 190.] 
numerous (8-10 on the lower, 2-4 on the upper) minute appendages, the arrangement of which could not well be determined. Each of these short-stalked appendages bears in its turn two, sometimes three, pollen-sacs, more or less pendulous, or with their apical portions directed obliquely outwards and downwards, below the somewhat swollen, often pointed apex of the appendage (Pl. XXXV, Fig. 2). In fact, the structure of each axillary axis of the capitulum is precisely that of the axis both in Ginkgo and Phyllocladus, axillary to scale-leaves of the brachyblast, which bears the numerous short appendages supporting pollen-sacs to the number of two or three. In Cephalotaxus, however, these axillary axes are arranged in the axils of bracts, in a compact inflorescence, whereas in Ginkgo and Phyllocladus each is perfectly isolated and independent.

The Structure of the Female Flower.

The small stalked capitula arise in the axils of scale-leaves, near the base of shoots of the year. Each produces three or four pairs of bracts exhibiting the opposite-decussate arrangement on the axis, thus differing in this character from those of the male capitulum. In the axil of each bract are two erect ovules, one on either side.

\section{Historical Notes.}

Most authors seem to be agreed as to the morphology of the male 'flowers' of the genus. Each axillary 'catkin,' as Eichler terms it, represents a single 'flower,' several of which go to constitute the capitulum which is an inflorescence. But one looks in vain in the textbooks for any definite detailed comparative treatment of the flowers, and yet this is the only sure method of determining their true morphological character. Čelakovský ${ }^{1}$ appears to be the only botanist who has given this subject the attention which it deserves, the only one who throws full and complete illumination thereupon. I will now 1890.

'Die Gymnospermen,' \&c. Abhandl. d. kgl. böhm. Ges. d. Wiss., vol. iv, 
proceed to demonstrate the morphology and homologies of the flowers as indicated by him.

Undoubtedly, the nearest allies of Cephalotaxus are Taxus, Torreya, Phyllocladus, and Ginkgo; of these Ginkgo and Phyllocladus almost certainly stand nearest to our genus. Each axis placed axillary to a bract of a male inflorescence is the homologue of the axis in Ginkgo and Phyllocladus, standing singly and alone in the axil of a scale-leaf or foliageleaf of the brachyblast or short shoot; this brachyblast is, therefore, probably homologous with the single inflorescence of Cephalotaxus, the difference from Ginkgo lying in the fact that in this latter genus the shoot possesses a vegetative apical bud and produces foliage- as well as scale-leaves, whereas in Cephalotaxus it only bears bracts. In Taxus and Torreya the male flowers also stand singly in the axils of the scale-leaves of short branches; unlike Ginkgo and Cephalotaxus, the axis of each flower of the two former genera bears several pairs of decussate bracts or sterile sporophylls ; in Phyllocladus a single such bract is present below the sporophylls.

The short stalks which bear the pollen-sacs are sporophylls of the primitive radially-symmetrical type, but represent a slight advance on the most primitive type of all represented by the case of Cordaites, in which the sacs are borne terminally on the radially-constructed sporophyll, for in Cephalotaxus and Ginkgo, Torreya, and Phyllocladus the sacs are subterminal and pendulous, owing to a slight prolongation of the axis of the sporophyll, between and beyond the sacs, into a small protuberance ; this condition of things is very interesting, for it marks an intermediate, transitional stage between the most primitive type of sporophyll (as seen in Cordaites, or, to take an instance from the Cycadales themselves, in Bennettites ${ }^{1}$ ) to that of Taxus, where the extended terminal portion of the sporophyll has become enlarged and flattened out into a very

1. Worsdell, 'The Affinities of the Mesozoic Fossil, Bennettites Gibsonianus Carr.' Ann. Bot., vol. xiv, September, I900.

D. H. Scott, Studies in Fossil Botany, Figs. 147,148, pp. 455, 456, 1900. 
distinct peltate structure bearing the pollen-sacs (here multiplied in number) on its lower and inner surface. It is the same radially-symmetrical, peltate type of sporophyll which occurs in that primitive group the Calamariae. Taxus thus represents an advance from the earlier types of Cephalotaxus, Ginkgo, \&c. towards the sub-peltate dorsiventral type of sporophyll of the true Coniferae. If the male 'flowers' of Taxus and Ginkgo, \&c. be regarded as 'cones,' that of Cephalotaxus would be a compound cone: considered apart from the nature of the lateral appendages, the relationship in this respect between the two former genera and the last-named is that existing between a raceme and a panicle; in other words, the flowers of Cephalotaxus pertain to a higher grade of branching than those of the other genera. The relationship may be thus expressed :-

Male Flowers.

\begin{tabular}{|c|c|c|c|c|}
\hline Ginkgo. & Phyllocladus. & Cephalotaxus. & Torreya. & Taxus. \\
\hline $\begin{array}{l}\text { Flowers single } \\
\text { in axils of scale- } \\
\text { or foliage-leaves. }\end{array}$ & $\begin{array}{l}\text { Flowers single } \\
\text { in axils of scale- } \\
\text { or foliage-leaves. }\end{array}$ & $\begin{array}{l}\text { Flowers group- } \\
\text { ed in compact in- } \\
\text { florescencein axils } \\
\text { of foliage-leaves. }\end{array}$ & $\begin{array}{l}\text { Flowers single } \\
\text { in axils of foliage- } \\
\text { leaves. }\end{array}$ & $\begin{array}{l}\text { Flowers single } \\
\text { in axils of foliage- } \\
\text { leaves. }\end{array}$ \\
\hline $\begin{array}{l}\text { Floral axis with } \\
\text { no bracts below } \\
\text { the sporophylls. }\end{array}$ & $\begin{array}{l}\text { Floral axis with } \\
\text { a single bract be- } \\
\text { low the sporo- } \\
\text { phylls. }\end{array}$ & \begin{tabular}{lr}
\multicolumn{2}{c}{ Floral } \\
with no bris \\
below \\
phylls.
\end{tabular} & $\begin{array}{l}\text { Floral axis with } \\
\text { bracts below the } \\
\text { sporophylls. }\end{array}$ & $\begin{array}{l}\text { Floral axis with } \\
\text { bracts below the } \\
\text { sporophylls. }\end{array}$ \\
\hline $\begin{array}{l}\text { Sporophylls ra- } \\
\text { dially-symmetrical } \\
\text { in structure. }\end{array}$ & $\begin{array}{l}\text { Sporophylls ra- } \\
\text { dially - symmetri- } \\
\text { cal in structure. }\end{array}$ & $\begin{array}{l}\text { Sporophylls ra- } \\
\text { dially - symmetri- } \\
\text { cal in structure. }\end{array}$ & $\begin{array}{l}\text { Sporophylls ra- } \\
\text { dially - symmetri- } \\
\text { cal in structure. }\end{array}$ & $\begin{array}{l}\text { Sporophylls ra- } \\
\text { dially-symmetrical } \\
\text { in structure: pel- } \\
\text { tate. }\end{array}$ \\
\hline $\begin{array}{l}\text { Pollen-sacs sub- } \\
\text { terminal, pendu- } \\
\text { lous. }\end{array}$ & $\begin{array}{l}\text { Pollen - sacs } \\
\text { subterminal, pen- } \\
\text { dulous. }\end{array}$ & $\begin{array}{l}\text { Pollen - sacs } \\
\text { subterminal, pen- } \\
\text { dulous. }\end{array}$ & $\begin{array}{l}\text { Pollen - sacs } \\
\text { subterminal, pen- } \\
\text { dulous. }\end{array}$ & $\begin{array}{l}\text { Pollen-sacs in- } \\
\text { serted on inner } \\
\text { surface of peltate } \\
\text { portion. }\end{array}$ \\
\hline
\end{tabular}

As regards the female flowers, Eichler ${ }^{1}$ held the short, secondary shoots of Taxus and Torreya, which bear each

${ }^{1}$ Eichler, 'Bluithendiagramme,' Theil I, p. 65, 1875. 
a terminal ovule, preceded by two or three pairs of bracts, to be homologous with a single ovule of Cephalotaxus, this latter being terminal to an axis whose lateral appendages have become completely abortive. He regarded the ovules of Ginkgo in the same light, each representing in itself a flower of which the 'collar' at the base is probably equivalent to a pair of bracts. It is probable, however, that he did not always retain these views, though I am unaware that he ever made any emendations to them.

Strasburger ${ }^{1}$ holds the same view as Eichler, regarding the two axillary ovules of Cephalotaxus seated on their short axis as constituting an inflorescence, each ovule representing the remnant of a secondary ovuliferous shoot like that of Taxus, the primary shoot between the two rudimentary axes being entirely suppressed. For Ginkgo and Phyllocladus he likewise affords us the same explanation, but the long-stalked 'inflorescence' of the former, especially when it bears two pairs of ovules, decussately arranged, is also comparable to the entire cone of Cephalotaxus.

Van Tieghem's ${ }^{2}$ view is very different indeed from that of either of the above authors; he interprets the axillary 'inflorescence' of Strasburger as the only leaf of a suppressed shoot, whose lamina has become reduced to the two ovules, in the same way as he regards the ovule of Taxus as the only leaf of an abortive tertiary axis. For Ginkgo he has precisely the same definition as for Cephalotaxus.

For myself, however, the views as to the morphology of the female flowers in this group which have been put forward by Čelakovský ${ }^{3}$ are the only tenable and true ones.

In their light we see that the primary shoot of Taxus and Torreya (and I have already in a previous memoir cited these various clearly-defined relationships ${ }^{4}$ ) is the homologue of the

1 Strasburger, Angiospermen und Gymnospermen, I879, p. 7 I.

2 Van Tieghem, Ann. d. Sci. Nat., Bot., $5^{\circ}$ sér., vol. x, I869, p. 28 I.

3 Čelakovský, 'Die Gymnospermen,' \&c. Abhandl. d. kgl. böhm. Ges. d. Wiss., vol. iv, i 890 .

4 Worsdell, "The Structure of the Female Flower in Coniferae; an Historical Study.' Ann. Bot., vol. xiv, 1900, pp. 74, 75 . 
entire plant of Cycads and the brachyblast of Ginkgo; the secondary shoots are the homologues of the Cycadean cone and the ovuliferous axis of Ginkgo. In Taxus, Torreya, and Phyllocladus the ovule, representing in itself the entire sporophyll or carpel, has become, owing to the peculiar conditions of space-adjustment on the shoot, perfectly terminal in position on the secondary floral axis; in Ginkgo the two ovules, as shown so remarkably well by the abnormalities described and figured in Fujii's ${ }^{1}$ memoir, and in that of Seward and Gowan ${ }^{2}$, are really, as in Taxus, \&c., reduced sporophylls, placed laterally on an axis whose terminal bud occasionally is formed; the sterile bracts of Taxus, \&c. are entirely absent.

Now, if we carefully and closely regard the excessively short axillary axes, each with its two transversely-placed ovules, in Cephalotaxus, we notice how similar each such tiny structure is to the much-elongated ovuliferous axis of Ginkgo, a kind of miniature copy of the latter, the only difference between the two really consisting in the extent of development of the various parts constituting each. In fact, we may safely regard the axillary structure in Cephalotaxus as in itself a 'flower,' i. e. an axis bearing sporophylls, which latter have become, as in Ginkgo, Taxus, \&c., reduced to ovules pure and simple. Hence the female flowers, like those on the male side, are arranged in an inflorescence, and pertain to precisely the same grade of branching, the only difference between the two inflorescences being that in the male structure the bracts are arranged spirally, in the female in decussate pairs. From all which we may gather that the 'primary shoot' of Taxus and Torreya, as also the short, fleshy ovuliferous axis of Phyllocladus, is the homologue of the inflorescence of Cephalotaxus. On this shoot there are: in Taxus a single fertile bract subtending a flower, and several sterile leaves; in Torreya a pair of fertile bracts and a single sterile one, thus

${ }^{1}$ Fujii, K., ' On the different Views hitherto proposed regarding the Morphology of the Flowers of Ginkgo biloba L.' Bot. Mag. Tokyo, vol. x, p. 7 .

${ }^{2}$ Seward and Gowan, 'The Maidenhair Tree (Ginkgo biloba L.).' Ann. Bot., vol. xiv, I900. 
two flowers; in Phyllocladus several alternating fertile bracts, thus several flowers; in Cephalotaxus several pairs of fertile bracts. As regards each individual flower: in Taxus are three pairs of sterile leaves and a single sporophyll reduced to an ovule in a terminal position; in Torreya are two pairs of sterile leaves and a terminal ovule; in Phyllocladus a single terminal ovule, the entire floral axis being abortive ; in Cephalotaxus, as in Ginkgo, are no sterile leaves and two lateral sporophylls reduced to ovules.

Here then we have the homologies and relationships between the different members of the group sufficiently clearly stated. I am of opinion that they express the true state of things much more nearly than do the views put forward by the authors cited above. I will now proceed to give some account of my own immediate observations on the female flowers of Cephalotaxus.

\section{ORIGINAL OBSERVATIONS.}

The tree from which the proliferating flowers were obtained stands in Windsor Park not far from Virginia Water. When quite young the tree was completely covered with a wire netting, doubtless with the object of preserving it from rabbits. This protection was, however, never removed, with the consequence that the tree during its subsequent growth became strangled and dwarfed in size, and lost its normal shape. There is a fine male tree standing near; but, although it produces flowers, pollen, I believe, is never shed; hence the flowers of the female tree could never be pollinated. I mention these two facts because it is possible that one or both of them may account for the proliferations of the female flowers.

I undertook the examination of these abnormal flowers in the hope that by means of them some direct light might be thrown on the morphology of the female flowers generally, for I am one of those who believe that abnormalities, if treated properly, may be of great value in this direction. 
At the outset I may state that proliferation both of the main axis of the inflorescence or of the axis of the individual flower may take place. According to the period, early or late, at which the phenomenon occurs, will the resultant structure vary. In the case of early, congenital proliferation of the inflorescence, the latter is entirely replaced by an ordinary but very short lateral vegetative shoot bearing spirallyarranged leaves, in which no trace of bracts or ovules are visible (Fig. 3), and which itself may produce inflorescences in its turn at the base. It may frequently attain an inch in length. Such a short vegetative shoot is much more nearly comparable to a brachyblast of Ginkgo, and serves to show that the homology suggested above as existing between the latter and the female inflorescence of Cephalotaxus may not be at all far-fetched. Indeed, the frequency of these proliferated inflorescences (I have heard of their occurrence elsewhere than in Windsor Park) strengthens the likelihood of their being the homologues of the brachyblasts of Ginkgo. Figs. 4-8 illustrate a few of these shoots alongside normal female inflorescences, in one of which latter is a leaf below the head of bracts inserted alone, as if representing the commencement of a spiral line.

If the proliferation of the primary axis has not occurred quite so early in the development of the shoot-not, in fact, until after the formation of the first pair of bracts-we obtain the case shown in Fig. Io, where, after the pair of bracts, which may be either fertile or sterile (i. e. contain no ovules in their axils), a vegetative axis bearing spirally-arranged leaves is laid down.

Again, proliferation may set in at a much later date, viz. after the formation of two or three pairs of bracts, of which the first pair may be alone fertile, and the third pair only distinguished from the spirally-arranged leaves of the apical bud by the fact of their apices not being adpressed to the bud, but projecting slightly outward (Fig. I4). The case shown in Figs. II and I 2 is that of an inflorescence which has made but a very feeble advance towards proliferation; the first and 
lowest pair of bracts and one of the second pair have been separated from the rest by a long internode, accompanied by a displacement of some of the bracts from their paired position, which possibly may represent a transitional step from the whorled arrangement of the bracts to the spiral insertion of the leaves of the vegetative shoot.

The apical region of an unproliferated primary axis of the inflorescence is usually considerably swollen, forming a conspicuous whitish object in the midst of the whole agglomeration of bracts, \&c. (Fig. 20). The swollen character is evidently due in part to the rudimentary bracts which build up this apical region, and sometimes project considerably as isolated protuberances in a lateral position and immediately above an axillary flower, so that I have often been led to imagine that this amorphous, rudimentary bract of the primary axis was an enlarged median posterior foliar organ of the axillary flower, and am still not perfectly clear as to how matters stand in all cases. This feature of the primary axis is exactly homologous with the still more swollen, fleshy character of the primary axis of Phyllocladus, in which the apex is equally undefined, and where several fleshy, sterile bracts frequently occur intimately fused with the axis bearing them. In fact, the inflorescence of Phyllocladus more nearly resembles that of Cephalotaxus than is the case with any other genus, the only difference being that in the former plant the bracts alternate and the floral axis is reduced to a single ovule (this being the lowest point reached in reduction of all the five genera), while in the latter genus the bracts are arranged in pairs, and the floral axis reduced to two ovules.

We next come to the consideration of the individual axillary flowers, which afford several points of considerable interest. Proliferated primary and secondary axes may occur on the same shoot, but by no means always accompany each other; indications of the latter may be present when the former are quite absent. The normal condition of things is that in which, on the excessively short axillary axis, either two lateral transversely-placed ovules are alone present, or sometimes between 
these, in a median position, a rudimentary foliar organ as well. I will now proceed to cite the various instances in which this normal state of things is departed from, and shall in every case speak of the whole axillary product as a 'flower.'

In comparatively few instances, the flower bore below the ovules and in a lateral position a pair of foliar organs ${ }^{1}$; in one or two cases, below these again, were rudiments of a second pair (Figs. I6 and I7). Of course, where two or three whorls are thus inserted, one immediately above and opposite the other, we must assume that one or more, in the latter case mentioned at least two, median whorls are theoretically present; but, owing to the extremely confined space existing between the bract and the primary axis of the inflorescence, have become crushed out of objective existence. However, in one flower examined, I found in the median anterior position, and below the insertion of the ovules, two exceedingly small rudiments one above the other, which quite probably represent two of the missing median whorls (Figs. I 8 and 19). The appearance of these two to four whorls of foliar organs below the ovules is very interesting, for it brings Cephalotaxus into line with Taxus and Torreya, which always normally possess these inferior whorls of leaves. Indeed, these two latter plants may be considered to possess, as compared with the case of Cephalotaxus, somewhat proliferated floral axes. Here, therefore, already is one result of the examination of these abnormal flowers: a new link is forged between the three genera, which, with others yet to follow, will help to substantiate their nearer relationships, along lines different from those usually conceived.

The ovules are themselves frequently replaced by, or metamorphized into, foliar organs of almost the same shape and size, but always somewhat lighter in colour and more pointed at the apex than the brownish ovules. Either one or both ovules may be thus metamorphosed. These two leaves in one

${ }^{1}$ In every case in which either this or the term 'leaf' is used in describing the following abnormalities, it denotes a very rudimentary structure, in no way resembling, either in colour, shape or size, a foliage-leaf. 


\section{'Flowers' of Cephalotaxus.}

inflorescence occurred on the axillary products of both bracts of the first pair, and in each case appeared as the first two leaves of the vegetative bud representing the proliferation of the floral axis, which is subtended by each bract (Fig. I3). From their position and appearance, there could be no doubt as to their representing metamorphosed ovules in all the cases in which I observed them. This is a matter of the first importance. If the two ovules are, in reality, as appears from these abnormal cases, foliar organs belonging to the short axillary axis, the theory of Eichler and Strasburger that each ovule represents an axis in itself of which the foliar organs situated below the terminal ovule are suppressed, entirely breaks down, and the view of Čelakovský receives additional support.

Sometimes the two lateral ovules are present in the form of foliar organs, while between them, in the median position, occur either one or two ovules representing the next succeeding pair (Figs. 12, 20-22). The presence of all four ovules, two in each pair, such as has been not infrequently observed in Ginkgo ${ }^{1}$, never came under my notice in the flowers I examined. We here see the opposite-decussate arrangement of the bracts on the primary axis of the inflorescence reappearing in that of the ovules and foliar organs on the secondary floral axes.

In one case which I observed, the flower consisted of the first lateral pair of foliar organs and a median pair, of which the posterior was developed as an ovule, and the anterior as a foliar organ, although of excessive minuteness (Figs. 23 and 24). Another flower exhibited a pair of lateral ovules and a median pair of organs, of which, conversely to the case just cited, the anterior was developed as an ovule and the posterior as a foliar organ (Fig. 25). In another flower, besides the lateral ovules, a pair of median organs of purely foliar nature was present (Fig. 19). In another, the median

1 Strasburger, loc. cit., P1. IX, Fig. I I, I 879. Čelakovský, 'Die Vermehrung der Sporangien von Ginkgo biloba L.' Fig. IA, Oesterr. Bot. Zeitschr., Jahrg. I900, Nos. 7,8 , and 9 . 
pair of foliar organs was reduced to a single anterior one (Figs. 28 and 29); that this latter was really anterior was shown by the fact of its concave surface being directed inwards, for I could discern no sign of the apical bud of the axis by which to orientate this leaf; it is interesting that this organ had the brown-coloured appearance usually exhibited by the ovules alone.

There came under my notice but a single example in which the floral axis simulated that of the primary axis at the apex in being swollen and enlarged and in having a foliar organ (in the posterior position) more or less fused with it.

The largest number of members ever seen on a floral axis was in a flower possessing two foliar organs and three ovules; it was impossible here to settle the true position of these five members, as displacement, arising from the confined and limited area of development, had evidently taken place.

The occurrence of a median pair of foliar organs may be regarded as an incipient stage in the transition to the complete proliferation of the axis of the flower. The next step in this direction is indicated by the case shown in Fig. 26, where, above the median pair, are two additional pairs of foliar organs. Fig. 30 represents a radial section through an axillary product at an early stage in its proliferation, showing two median leaves with the minute apical bud between them. The two lateral ovules are indicated by dotted lines. Here, although fewer foliar organs are present, the proliferation is really at a more advanced stage than in the last-mentioned case, for the axis is considerably developed and a vegetative bud already formed at the apex. Complete proliferations are shown in Figs. 13, 14, 34.

Commonly, the axillary bud causes a wide separation of the two lateral ovules as it emerges from between them, so that each projects considerably beyond the margin of the bract on either side. It also not infrequently induces the inclination of the primary axis from the vertical plane, so that the inflorescence becomes quite curved.

In one instance in which an axillary bud was present, there 
were found four members belonging to the axis below the vegetative bud; these were-a lateral ovule and a lateral foliar organ (representing the normal ovule of the opposite side), a median posterior ovule, and a rudimentary foliar organ below the lateral ovule (Fig. I4). With regard to these leaves, which sometimes appear below the first normal pair of members, I may say that their frequent occurrence, either as developed or rudimentary organs, is sufficient to indicate the actual presence of an axis below the ovules, upon which the latter are borne as foliar members, such as is found in Taxus and Ginkgo. The occurrence (I) of these lowest foliar organs on the single axis, (2) of ovules metamorphosed into leaves ${ }^{1}$, and (3) of the single proliferated axillary axis, are each and all of them sufficient to refute the theory of Eichler and Strasburger, much more that of Van Tieghem, and to establish the plausibility of the theory put forward by Čelakovský.

I may here conveniently submit a comparative table of the characters of the female flower of all the members of the group, which is compiled according to the views on the subject which I hold to be the true ones (p. 650). I have added thereto, at the end, the characters of the ovular integuments.

\section{SUMMARY:}

The contents of the foregoing pages may be thus summarized :-

I. Cephalotaxus, both in its male and female flowers, exhibits close similarities and relationships to Ginkgo, Taxus, Torreya and Phyllocladus. It is only by a careful comparative study of both normal and abnormal structures in these five genera, and of Cycads, that a true comprehension of the morphology of their flowers can be arrived at.

2. Proliferation of the primary axis of the inflorescence of

1 The ovule being, as I hold, homologous with a leaflet or segment of a carpel or sporophyll, the structure here described as replacing the ovule, and almost identical with it in size and shape, will probably represent a sporophyll reduced to one of its segments or leaflets rather than an entire foliar structure. 


\section{Worsdell. - The Morphology of the}

\begin{tabular}{|c|c|c|c|c|c|c|c|}
\hline $\begin{array}{l}\text { हैँ } \\
\text { हैँ } \\
\text { है }\end{array}$ & 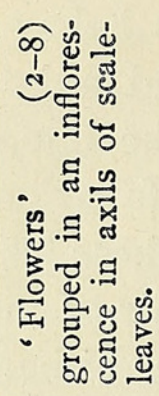 & 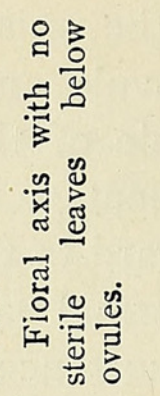 & 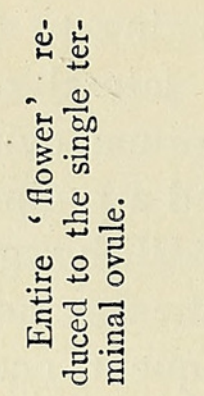 & 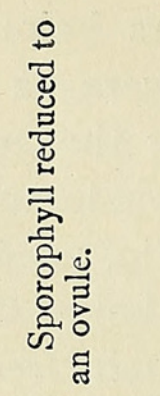 & 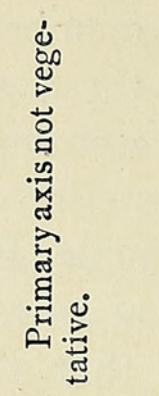 & 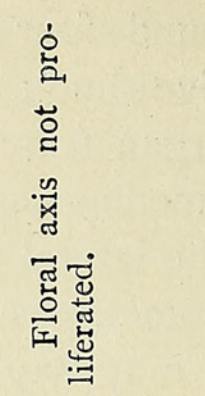 & 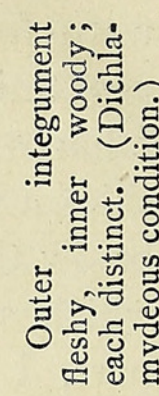 \\
\hline 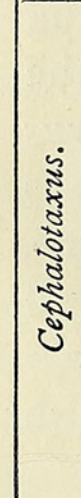 & 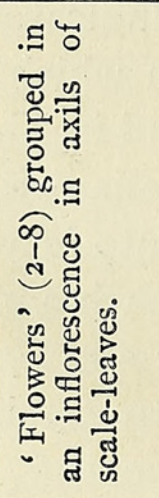 & 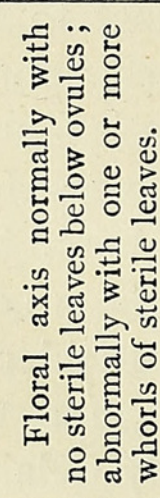 & 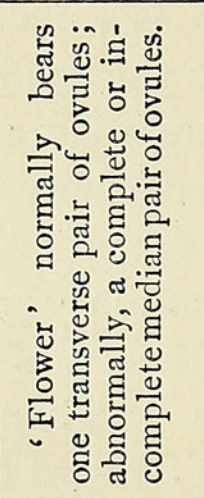 & 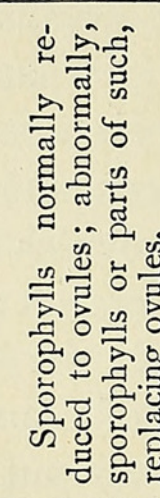 & 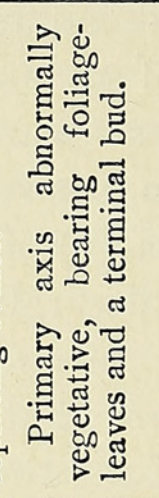 & 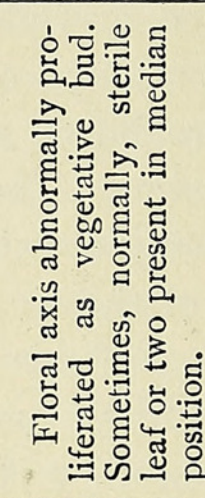 & 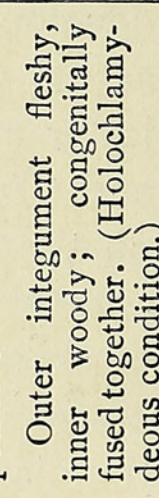 \\
\hline है & 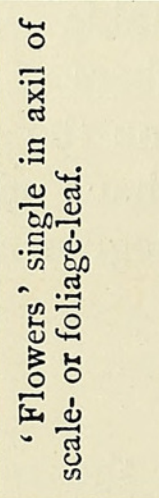 & 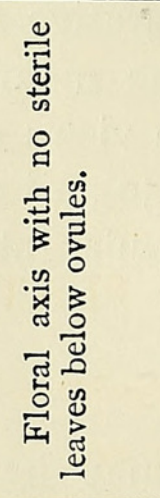 & 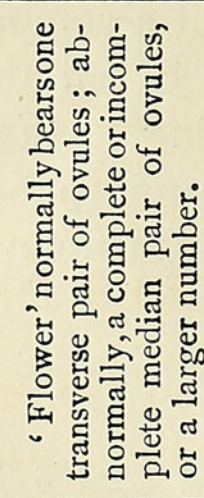 & 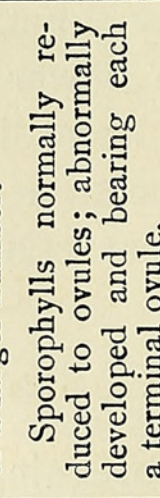 & 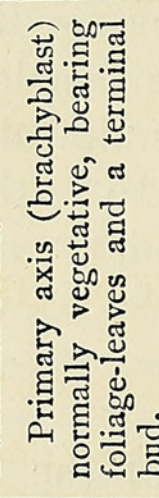 & 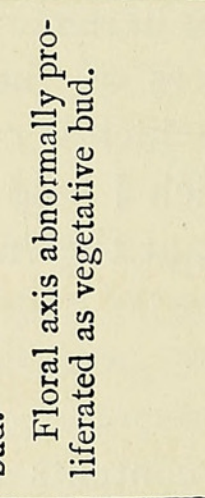 & $\begin{array}{l}5 \\
5 \\
5\end{array}$ \\
\hline हुँ & 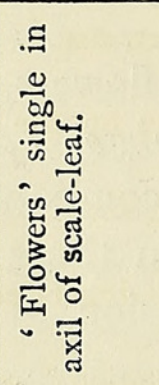 & 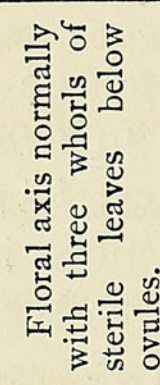 & 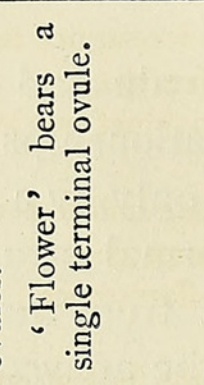 & 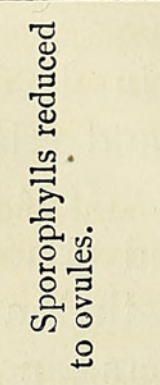 & 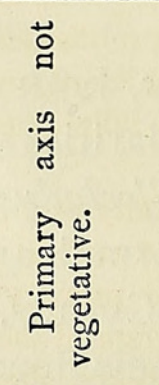 & 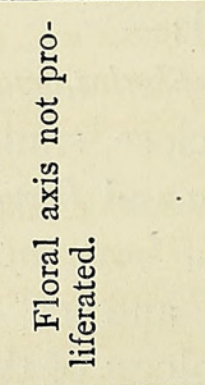 & 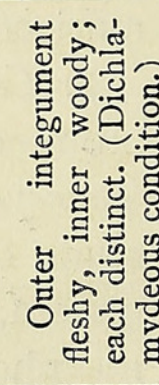 \\
\hline & 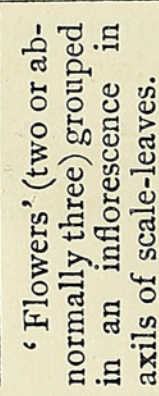 & 管 & 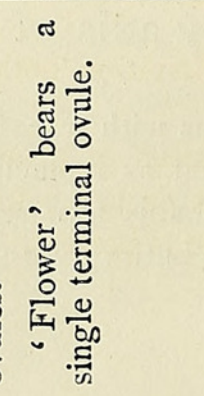 & 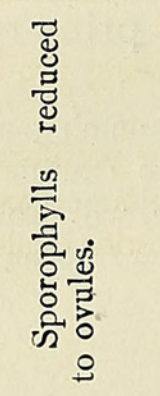 & 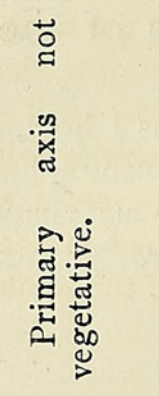 & 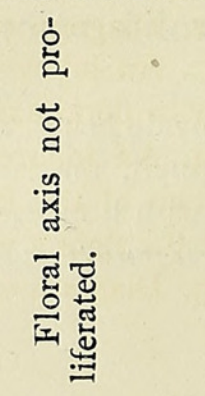 & $\bar{b}$ \\
\hline
\end{tabular}




\title{
'Flowers' of Cephalotaxus.
}

the female flower may occur, in greater or less degree, according to the period at which it sets in.

3. Proliferation of one or more secondary or 'floral ' axes may occur. The various tendencies to proliferate are shown in the metamorphosis of the ovules into foliar organs, the occurrence of foliar organs, rudimentary in character, both above and below the insertion of the ovules.

4. Each female 'flower' is shown by the proliferations to be an axillary axis bearing foliar organs arranged on the oppositedecussate plan, being in this respect a reproduction of the primary axis.

In conclusion, I may say, that it is to the acute powers of observation of Miss Benson and, I believe, of one of her pupils, Miss Sanday, who first detected the abnormal flowers, that I am indebted for any results which may have accrued from their examination.

\section{EXPLANATION OF FIGURES IN PLATE XXXV.}

\author{
Illustrating Mr. Worsdell's paper on Cephalotaxus.
}

Fig. I. Male inflorescence; from a photograph. Nat. size.

Fig. 2. Male sporophyll or stamen.

Fig. 3. Shoot with proliferated female inflorescence in situ. Nat. size.

Fig. 4. Normal female inflorescence. Nat. size.

Fig. 5. Sub-normal inflorescence with a bract or leaf halfway up the stalk. Nat. size.

Figs. 6-8. Congenitally proliferated female inflorescences. Nat. size.

Fig. 9. Diagram of a normal female inflorescence.

Fig. 10. Proliferated primary axis of inflorescence; one pair of bracts present. $\times 7$. Fig. Ioa. Diagram of the same.

Fig. Ir. An inflorescence, showing a slight indication of proliferation. $\times 3 \frac{\mathrm{I}}{2}$.

Fig. I2. Diagram of the same.

Fig. I3. An inflorescence, showing proliferation both of the primary and two secondary or floral axes. $\times 7$.

Fig. I4. An inflorescence with proliferation of primary and of one secondary axis; in two of the flowers a foliar organ occurs below a lateral ovule; in the flower on the right a median posterior ovule is present. $\times 7$.

Fig. 15. Diagram of the same. 
Fig. 16. Tangential section of a flower, showing a foliar organ below each of the lateral ovules, and rudiments of others still lower on the axis. $\times 20$.

Fig. 17 . Diagram of the same.

Fig. 18. Radial section of a flower, showing two median rudimentary foliar organs; the larger organ $b$ is probably a median bract of the inflorescence. $\times 30$.

Fig. 19. Diagram of the same.

Fig. 20. An inflorescence with the insertion of three pairs of bracts indicated; in the median flower one of the lateral ovules is replaced by a foliar organ, and a median ovule is also present; the bract removed. $\times 7$.

Fig. 21. Flower with three ovules; bract removed. $\times 7$.

Fig. 22. Flower with both lateral ovules replaced by foliar organs, and a median ovule present; bract removed. $\times 7$.

Fig. 23. Radial section of a flower, showing position of a median ovule and foliar organ. $\times 20$.

Fig. 24. Diagram of a flower with the two lateral ovules replaced by foliar organs, and with a median ovule and foliar organ.

Fig. 25. Diagram of a flower with median ovule and foliar organ.

Fig. 26. Diagram of a flower with one of the lateral ovules replaced by a foliar organ, and with two median pairs and one transverse pair of foliar organs-the most primitive stage in the proliferation of the flower.

Fig. 27. Diagram of a flower in which lateral ovules are replaced by foliar organs, and with a median pair of foliar organs and ovules.

Fig. 28. Flower in axil of bract with one of the lateral ovules removed (indicated by dotted line) to show a median foliar organ. $\times$ Io.

Fig. 29. Diagram of the same.

Fig. 30. Radial section of a flower, showing an early stage of proliferation; the lateral ovules indicated by dotted lines. $\times 3^{\circ}$.

Fig. 3I. Diagram of the same.

Fig. 32. Radial section of a flower, showing two median foliar organs. $\quad \times 20$.

Fig. 33. Ditto, showing median posterior foliar organ and axis of flower. $\quad \times 30$.

Fig. 34. Two proliferating axes, one of which is a floral axis, the other of uncertain position.

The following are the abbreviations used :-

$a p . b d=$ Proliferating apex of the primary axis.

$a x, b d=$ Proliferating apex of the floral axis.

Ir $=$ Rudiment of foliar organ.

$l=$ Foliar organ situated below insertion of lateral ovules.

$l^{1}=$ Foliar organ which replaces a lateral ovule.

$l^{2}=$ Median foliar organ.

$o v^{1}=$ Lateral ovule.

$o v^{2}=$ Median ovule.

$b r^{1}, b r^{2}, b r^{3}, b r^{4}, b r^{3}=$ Bract of Ist, 2nd, 3rd, 4th, and $\xi^{\text {th }}$ pair respectively.

$a x_{0}$ inf.$=$ Primary axis.

$a x . f_{0}=$ Floral axis.

$\not f f_{\text {. infl. }}=$ Proliferated inflorescence.

$x=$ Position of some missing structure, either ovule or bract. 


\section{Annals of Botany}
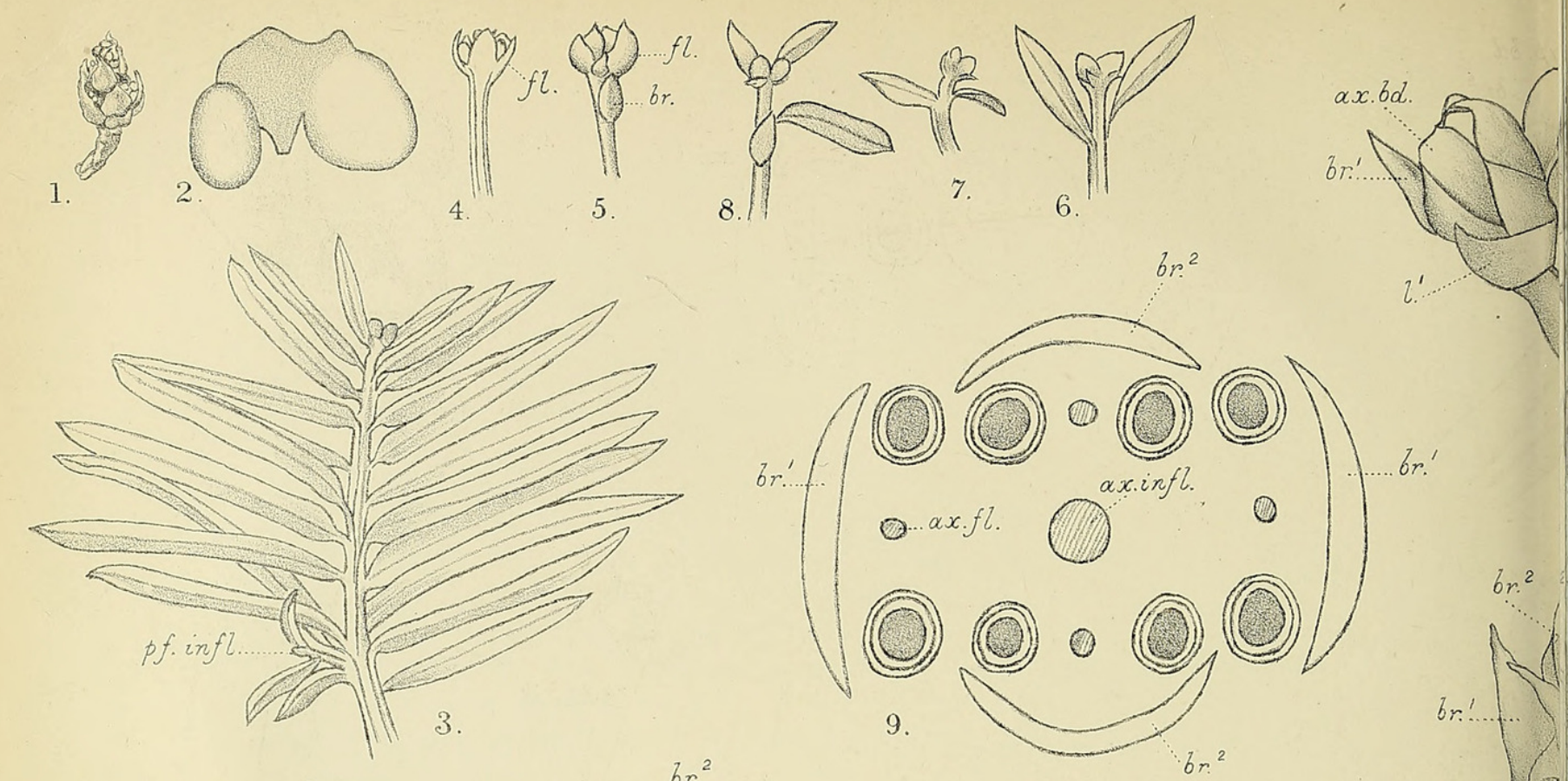

$6 r^{2}$
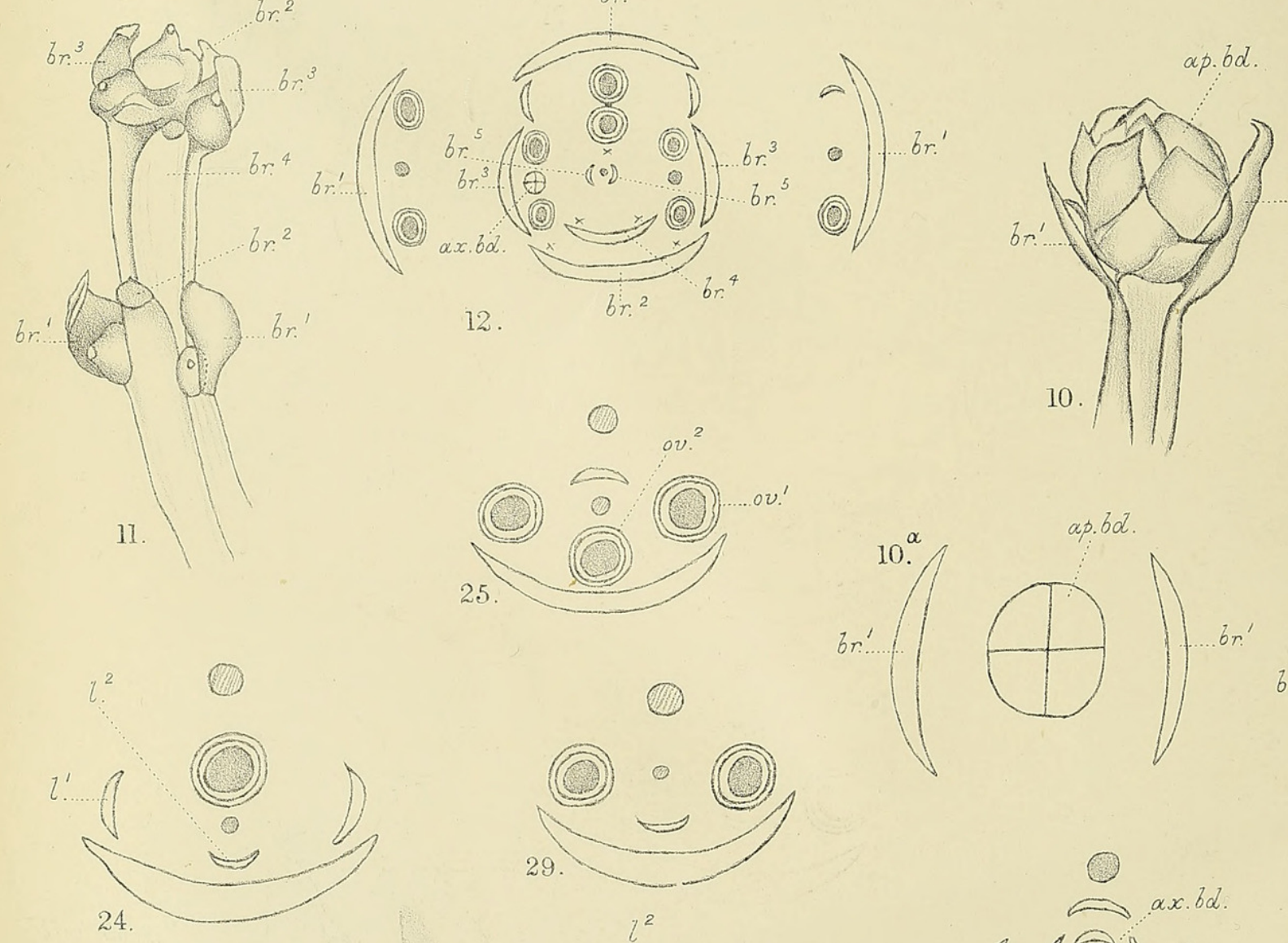

$$
12 .
$$
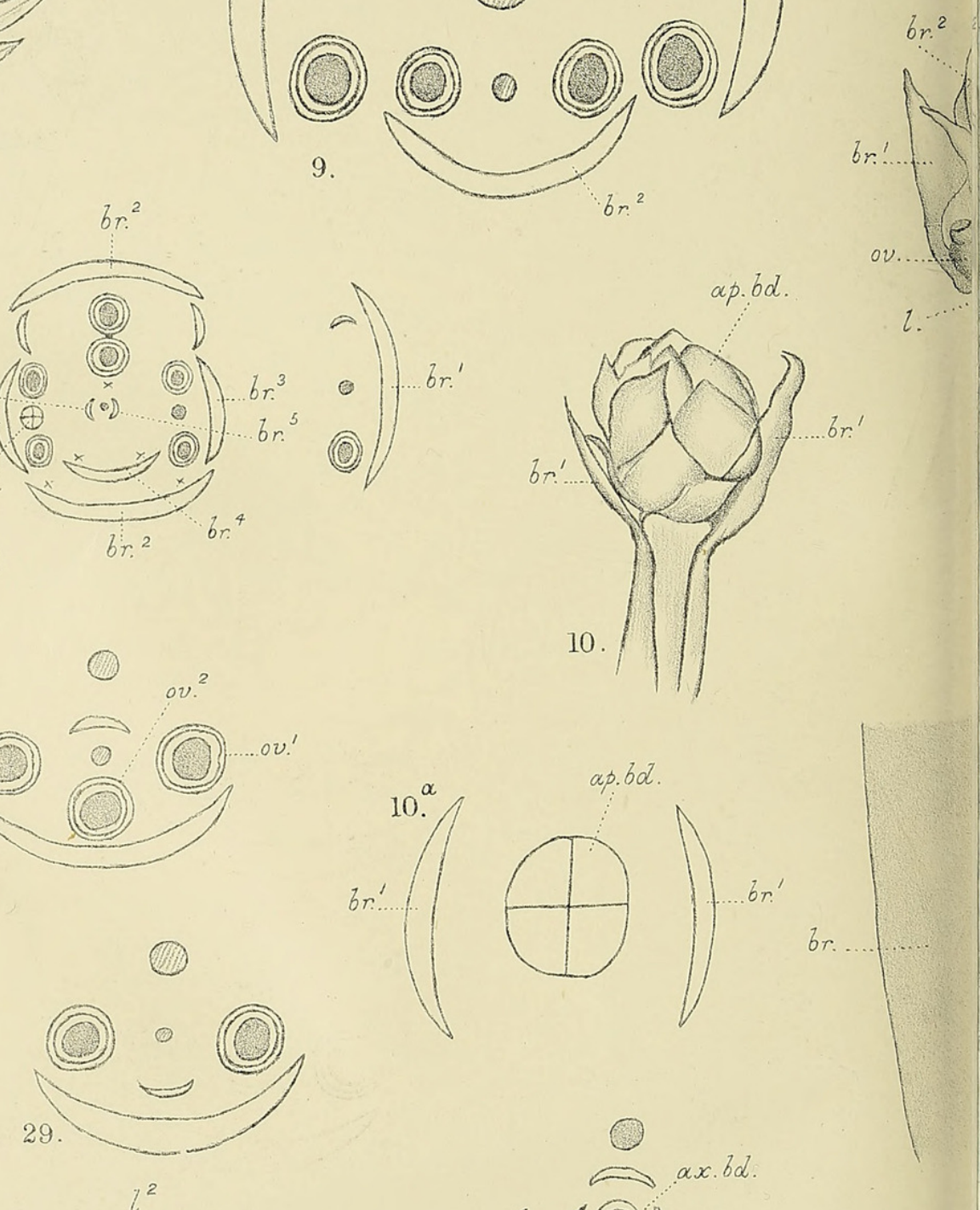

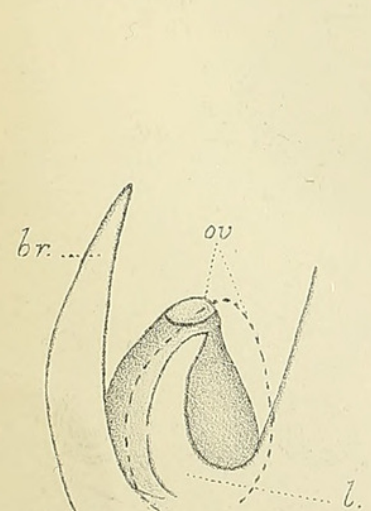

28.

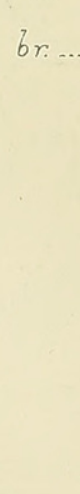

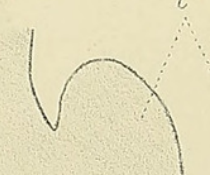

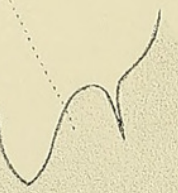

ax.infl.
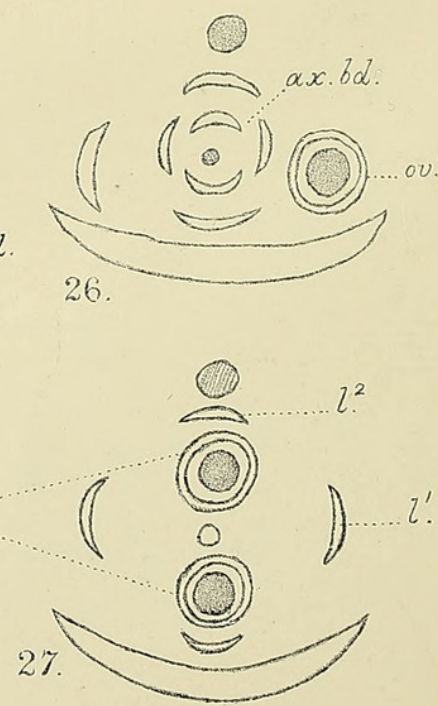
Annals of Botany

Vol.XV. Pl. XXXV.

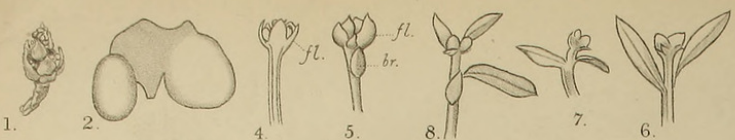
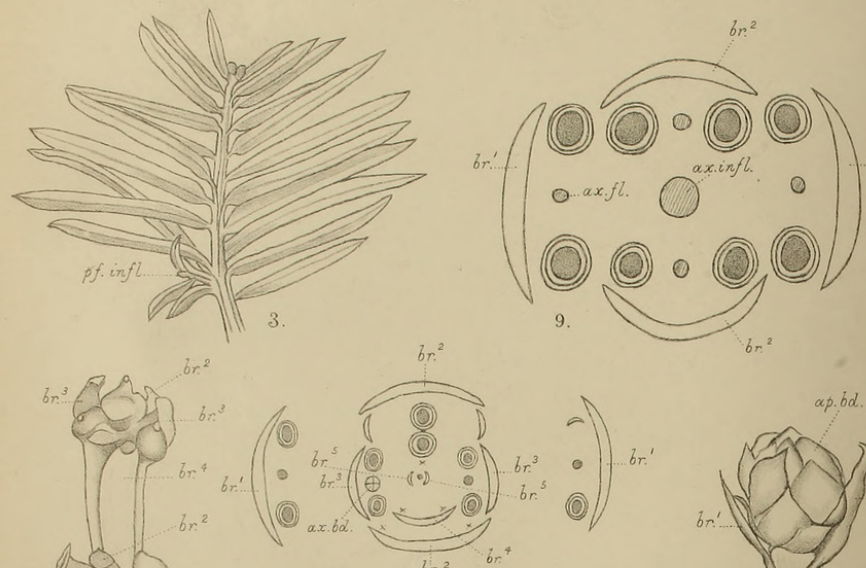

(3) $b$

11.

(1)

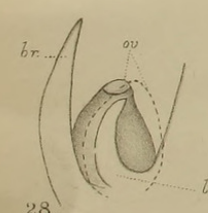
w. C. w. del.
(1) $o v^{2}$

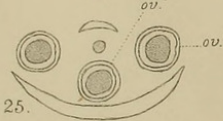

(0)

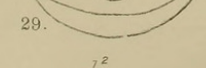

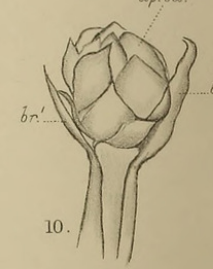
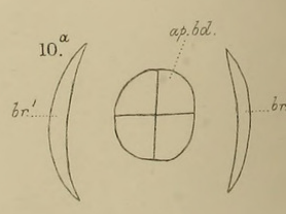

$\curvearrowright \alpha x . b d$.

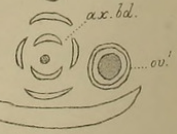

-
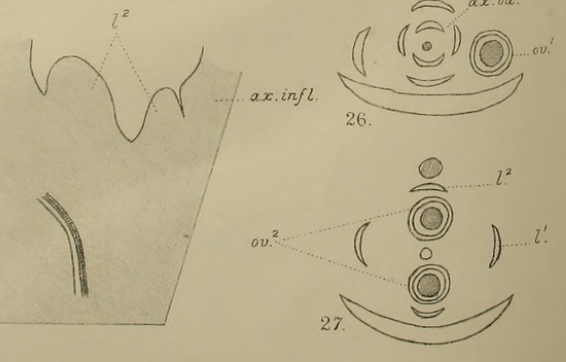

Mpen

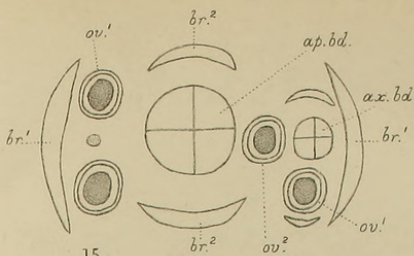

13.

$r^{2}{ }^{a p} . b d$

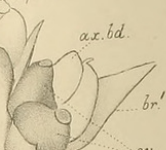

14

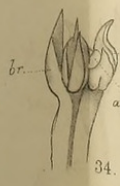

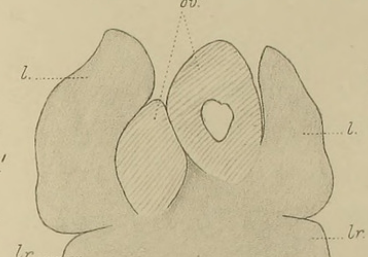

or<smiles>[14CH3]</smiles>

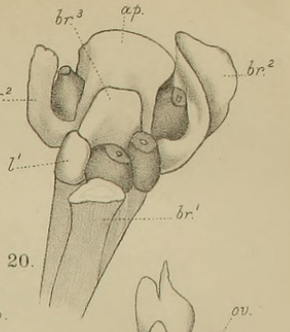

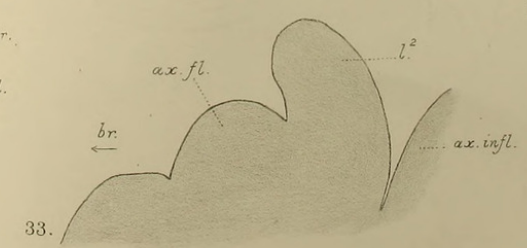

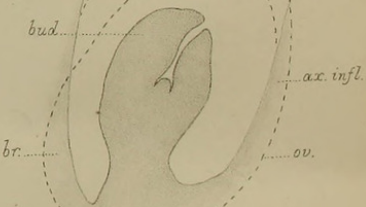

30

$O_{a x . b d .}$

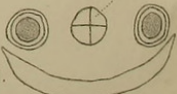

University Press, 0xford 


\section{$2 \mathrm{BHL}$ Biodiversity Heritage Library}

Worsdell, Wilson Crosfield. 1901. "The morphology of the 'flowers' of Cephalotaxus." Annals of botany 15, 637-652.

https://doi.org/10.1093/oxfordjournals.aob.a088842.

View This Item Online: https://www.biodiversitylibrary.org/item/236929

DOI: https://doi.org/10.1093/oxfordjournals.aob.a088842

Permalink: https://www.biodiversitylibrary.org/partpdf/318646

\section{Holding Institution}

Smithsonian Libraries

\section{Sponsored by}

Biodiversity Heritage Library

\section{Copyright \& Reuse}

Copyright Status: Not in copyright. The BHL knows of no copyright restrictions on this item.

This document was created from content at the Biodiversity Heritage Library, the world's largest open access digital library for biodiversity literature and archives. Visit BHL at https://www.biodiversitylibrary.org. 